
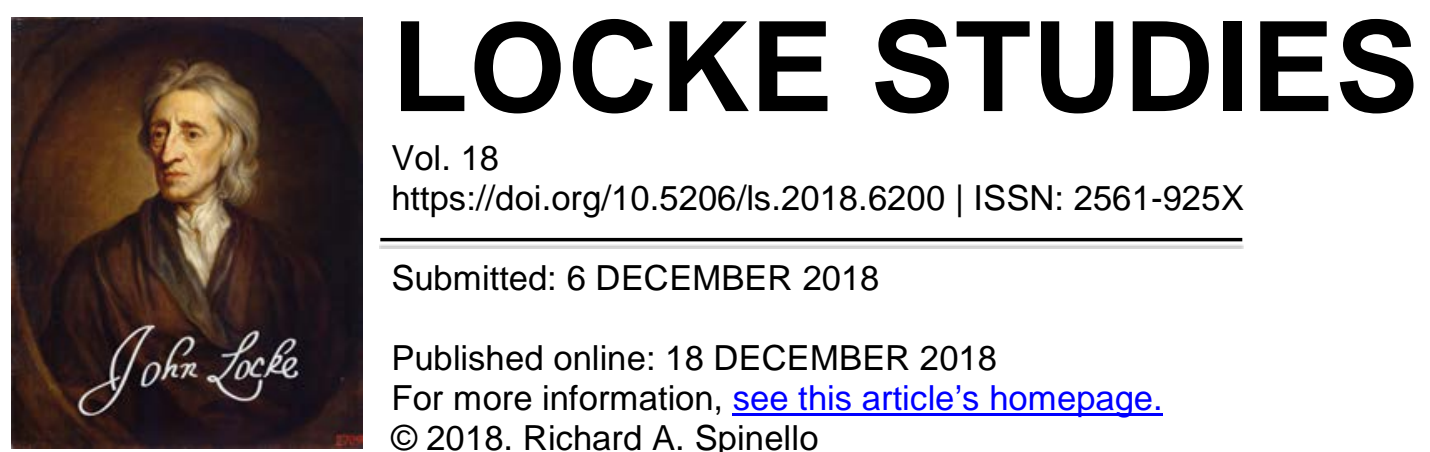

Vol. 18

https://doi.org/10.5206/ls.2018.6200 | ISSN: 2561-925X

Submitted: 6 DECEMBER 2018

Published online: 18 DECEMBER 2018

For more information, see this article's homepage.

(C) 2018. Richard A. Spinello

\title{
Review of The Intellectual Properties of Learning: A Prehistory from Saint J erome to J ohn Locke by J ohn Willinsky
}

\author{
RICHARD A. SPINELLO \\ (CARROLL SCHOOL OF MANAGEMENT, BOSTON COLLEGE)
}

Abstract:

A review of J ohn Willinsky's recent book, The Intellectual Properties of Learning: A Prehistory from Saint J erome to J ohn Locke (Chicago: University of Chicago Press, 2017).

Keywords: accreditation, author rights, commonwealth of learning, humanism, open access, scholasticism 
Willinsky, J ohn. The Intellectual Properties of Learning: A Prehistory from Saint J erome to J ohn Locke. Chicago: University of Chicago Press, 2017, 368 pages, \$40 (hbk). ISBN 9780226487922.

\section{Reviewed by RICHARD A. SPINELLO}

In the eyes of many scholars, networked information technologies were supposed to enhance freedom and equality. But these ideals clearly have not been realized, despite the global diffusion of these systems. Part of the problem has been the strict enforcement of copyright law in many regions of cyberspace along with the use of code or software that encloses online content. Corporate and individual authors have asserted their economic and non-economic rights to control who gets access to their works. Legal cases such as Napster and Grokster now fill the law books, and the blocking of information flows has become routine. At the same time, information libertarians resist these trends and demand more openness in cyberspace as well as the emancipation of content from intellectual property restrictions.

J ohn Willinsky's fine book The Intellectual Properties of Learning is a masterful and comprehensive exposition of the prehistory of intellectual property rights and the conflicts that ensue when those rights are legally enforced. The author's aim is to decipher what light the flux of history might shed on determining the proper scope of copyright protection. Borrowing a phrase from John Locke, he bids us to focus on the "commonwealth of learning" and its steady evolution. As Willinsky mentions, this phrase provides a powerful image for his book because it suggests an autonomous and selfgoverning state, "one that the learned have founded for themselves, with their work constituting a wealth held in common" (17). Moreover, we can best learn about this sovereign commonwealth by studying the history of learning in order to ascertain the fundamental properties of learning. What emerges in this historical study is that scholarly works constitute a distinct type of intellectual property that deserve to be treated differently from other works eligible for copyright protections.

Willinsky begins his historical overview by carefully examining the medieval monastery, which sought to preserve the intellectual patrimony of the West even as public order collapsed. Also considered in this context is the abrupt rise of Christian intellectual life. For primitive Christianity, philosophy and ancient wisdom played virtually no role in its pedagogy. However, this all changed with learned scholars like Augustine of Hippo, who helped to inspire the Church's transition from credo quia absurdum to fides quaerens intellectum. Augustine thereby settled Bernard's rhetorical question "What has Athens to do with Jerusalem?" by overcoming the antithesis between classical and Christian cultures.

Augustine and other Church Fathers cultivated an atmosphere of learning from the accessible and uncopyrighted texts of great philosophers like Plato, who urged a sojourn from the world of shadows into the world of Ideas illumined by the supreme Idea known as the Good. Plato's philosophy along with that of neo-Platonists, like Plotinus, givestrong intellectual support to Christian principles such as the supersensible world and the soul's immortality. According to Willinsky, one finds in the works of Augustinea modest defense of the right to use the text of one's philosophical predecessors. Scholars could generously borrow from these works of the Greeks and classical culture because the "beauty of truth and wisdom" cannot be the exclusive property of anyone (34). Augustine, therefore, 
strongly supported the right of inquiry, and this sets the pattern for the whole Middle Ages. But the liberal arts tradition that formed Augustine as a scholar was lost after the fall of Rome at the hands of the barbarians.

In the early Middle Ages (the fifth to the tenth centuries) the monastery emerged as a secluded intellectual center for composing, compiling, and copying manuscripts, including those of Augustine and other Christian thinkers. Many individuals were engaged in supporting the use of these works-not just authors, but also translators, reviewers, and editors. Sizable donations from wealthy patrons greatly helped this effort. Patronage has always been an essential element in the promotion of learning and the conservation of texts and manuscripts. By the eleventh century as erudition became central to monastic life, great medieval thinkers emerged, including Anselm, Peter Abelard, Hildegard of Bilgen, and Bernard of Clairvaux. They, too, drew inspiration from the available works of pagan philosophers in order to thematize Christian experience. At the same time, learning was being widely disseminated through Hildegard's preaching tours or Abelard's establishment of schools.

In the next century, there was a shift in momentum from the rural, isolated monasteries to urban areas. The newly formed universities provided more formal opportunities for erudition and scholarship. The university became the intellectual center of Christian life as the old monastic schools declined. The University of Paris, which began in 1170, was a place of unrivaled intellectual vitality where both Christian and rationally grounded secular wisdom was preserved and transmitted. Through contact with Arabic Muslim culture, all of Aristotle's works (many of which had been lost to the West) entered Western intellectual culture through a massive translation work. This "wealth of access" permanently altered the "direction and institutional setting of learning" (111).

Thanks to the translation of these Aristotelian texts, new doctrines and methods become known through university faculties. Despite its anti-Christian elements, such as the denial of creation, Aristotle was purified and synthesized with Christian revelation by scholars such as Albert the Great and Thomas Aquinas. For this momentous task they needed unencumbered access to the texts of Aristotle and his Arab commentators. The university system ensured that that these and other learned texts were easily accessible. At universities like Paris the scholastic tradition was incubated. Despite the intellectual protections of an author's work in place by the thirteenth century, which assured proper accreditation, the "right of use" becomes even more pivotal for the dialectical scholastic process and for the advance of higher education. There were no questions raised about the rights to quote extensively from these translated works and their commentaries in order to complete the task of synthesizing Christian and secular wisdom. One can certainly infer that Aquinas might have had a more difficult time fusing these diverse patrimonies into a new synthesis if these works had been protected by copyrights.

The Scholastic tradition of Aquinas and his peers was followed by the humanist revival. Humanists ranging from Petrarch to Erasmus recovered and restored a body of Greek, Roman, and Christian texts. The humanist period which lasted from thefourteenth through the seventeenth centuries represented a return to classic literature which was not to be interpreted through the lens of scholastic philosophy. According to Willinsky these humanists introduced "a particular set of disciplinary concerns with the rhetorical, intellectual, and literary properties of the works that constituted classical antiquity" (206). Scholars like Erasmus also promoted education in the humanities in order to form 
the well-educated, well-rounded person with classic view of man and culture. This aristocracy of culture could help to build a new era of humanist enlightenment.

The age of print, which began with Gutenberg's invention of the printing press, had a disruptive but salutary influence on learning and scholarship. Willinksy links this development with the emergence of the Italian humanist academies, gatherings of professors, monks, clergy, and others who came together to share books and present papers that took advantage of the printing press. Through these academies we can discern the benefits of collaboration and the communal aspects of learning. With the help of print, these academies achieved intellectual independence by publishing their own books and manuscripts. However, the values associated with commerce sometimes conflicted with learning's distinctive properties of autonomy, access, and communality.

During the reformation, Henry VIII disbanded the English monastery and remaining monastic colleges, thereby putting an end to the "scholar-monk's" efforts to sustain classical learning. But new universities like Oxford appeared on the scene. The monastic manuscripts and sources of learning were preserved in the Bodleian and other libraries. The Bodleian Library worked out an arrangement with medieval publishing guild known as the Company of Stationers to initiate the practice of free deposit of publications in this library and a few others. With this transition the intellectual property value of learned works actually increased as they were catalogued, preserved, and edited. Once again, patronage was especially important as wealthy donors made possible a "new level of institutional commitment to learned curation and public access" (268).

At the end of his historical survey, Willinsky turns his attention toJ ohn Locke's theory of property presented in the Two Treatises of Government. He reviews Locke's familiar rationale for property ownership, but the main axis of discussion is how Locke's famous theory "can also serve as a guide to that distinctive class of intellectual property associated with learning" (281). He argues that one finds in Locke's view of labor as the foundation for property rights a selective right to work on others' intellectual works in order to bring greater meaning and coherence to those works. Willinsky points out that while Locke refers to the "labor of thought" as well as "learned and laborious inquiries" he does not assert that such labor gives rise to a justified property claim (286).

The author finds warrant for his unorthodox interpretation of Locke in the work of the eminent Locke scholar, J ames Tully. In his estimation, Tully was far more attuned than others to the humane and communitarian side of Locke that is obfuscated by standard libertarian interpretations. Tully stresses the moral limits inherent in property rights, which are especially relevant for learning's intellectual properties. In this case, property rights "are about collective standards around accreditation and use, rather than absolute or unqualified possession" (292).

In his conclusion to these arguments, Willinsky provides a brief summary of learning's properties that have become evident through his historical sojourn. Those properties include: access, accreditation, autonomy, communality, sponsorship, and use. But learning's earlier prominence, evident even in the Statute of Anne (1710), "has been overshadowed by the economic engines of corporate patents and commercially exploited copyright" (319). Academic journals and scholarly books are no longer treated as sacred sources of learning that demand open access. Rather, they have become economic commodities that exclude those who cannot afford the purchase price or licensing fees. What's the solution to this problem that thwarts current research efforts? Willinsky recommends a distinct legal class of intellectual property associated with learning that 
would include scholarly journals, data sets, historical sources. He recommends new legislation, a revision of copyright law, which would require that a Creative Commons license be applied to ensure communal access but also protect the accreditation or proper crediting of the work.

Now that we have summarized this book we can climb to higher ground and critically survey the landscape. On a purely practical level, it is not completely clear how this new class of intellectual property would be financed. Willinsky offers some suggestions, but the production of scientific and academic journals is an expensive proposition and publishers typically require a financial incentive to make such an investment. The substitution of open access for paid purchases could undermine markets for these works that bear some of learning's distinct properties. Second, on a theoretical level, it is difficult to accept the conclusions of Locke scholars like Tully and their communitarian perspective that intellectual works belong to the community rather than the individual. Locke's main thesis is that people have a property right, understood as the right to exclude, in themselves, in their labor, and in the objects created by that labor. Thanks to the sufficiency proviso, which mandates that the others have access to the same original or common material that the individual author used, and the charity proviso, Locke's essential theory may be more modest than some of his supporters are willing to admit. But the transformation of pre-existing intellectual material into a new work through the expenditure of labor gives rise to a property claim even if that new thing exhibits some of the properties of learning. So long as the property claim does not extend to common ideas, algorithms, or other material in the intellectual commons, this new expression warrants a property right.

Is it possible to reconcile Locke's elegant justification for individual property rights with the communitarian views of Tully and Willinsky? Willinsky wants to recruit Locke for his cause of open access (under a "Creative Commons" license), and there is certainly some merit to the argument that such access for academic journals and scholarly books would enhance social welfare. But it is far from evident that Locke would be an ally in the effort to win this right for uncompensated access against the author's wishes. Locke's theory strongly implies both economic and non-economic rights for creative efforts, including those that lead to the socially valuable goods described by Willinsky. The current legal system has safety valves such as the fair use provision of copyright law, but intellectual property law that is consistent with Locke's philosophy must guarantee appropriate rewards for creators and authors. To be sure, authors' rights are not absolute and there may be some exigent circumstances where academic studies and journals need to be made available without proper compensation. But to argue that as a general rule works that bear the intellectual properties of learning are not subject to traditional property protection would be a subversion of those author's rights that are so central to Locke's understanding of property.

Carroll School of Management, Boston College 